\title{
ANALISIS KADAR TIMBAL (Pb) PADA AIR SUMUR GALI DI KAWASAN TEMPAT PEMBUANGAN AKHIR SAMPAH BANJAR SUWUNG BATAN KENDAL DENPASAR SELATAN
}

\author{
Kadek Ayu Tia Surya Handriyani ${ }^{1}$, Nur Habibah², I Gusti Ayu Sri Dhyanaputri ${ }^{3}$ \\ 1,2,3 Jurusan Analis Kesehatan, Politeknik Kesehatan Kemenkes \\ Denpasar, Indonesia \\ e-mail: nur.habibah.poltekkesdps@gmail.com
}

\begin{abstract}
Abstrak
Tempat Pembuangan Akhir (TPA) Sampah Suwung merupakan salah satu TPA di wilayah Kota Denpasar yang masih menggunakan sistem open dumping dalam teknik pengolahan sampah. Hal ini sangat berpengaruh terhadap kualitas air tanah di sekitarnya, sedangkan diketahui bahwa penduduk sekitar TPA masih memanfaatkan air sumur gali sebagai sumber air utama. Salah satu jenis polutan berbahaya yang terkandung dalam sumber air di wilayah TPA adalah logam berat. Penelitian ini dilakukan untuk mengetahui kadar timbal $(\mathrm{Pb})$ pada air sumur gali di TPA Suwung dengan metode deskriptif menggunakan pendekatan observasional sedangkan pemeriksaan kadar timbal dilakukan dengan metode spektrofotometri serapan atom (SSA). Berdasarkan hasil penelitian diketahui bahwa kandungan timbal dalam sampel air sumur gali bervariasi antara $0,0060 \mathrm{mg} / \mathrm{L}$ hingga $0,1023 \mathrm{mg} / \mathrm{L}$. Berdasarkan hasil tersebut diketahui bahwa terdapat sampel yang memiliki kandungan timbal melebihi ambang batas maksimum yang diijinkan oleh Permenkes RI No. 416/MENKES/PER/IX/1990. Tingginya kadar timbal ini kemungkinan dipengaruhi oleh jarak sumur gali dari TPA yang tidak memenuhi syarat sehingga mempermudah terjadinya pencemaran. Selain timbal, terdapat beberapa parameter lain yang dianalisis dalam penelitian ini antara lain kekeruhan, warna dan suhu sampel.
\end{abstract}

Kata Kunci: TPA Suwung, Analisis Timbal, Spektrofotometri Serapan Atom

\begin{abstract}
Final Waste Disposal Area at Suwung, Denpasar is one of the final waste disposal areas that use an open dumping system for waste management techniques. These waste management techniques cause a lack of groundwater quality. On the other hand, this groundwater is still being used as the main water source by the residents around the final waste disposal area. The study aimed to determine the lead concentration in the well water at the Suwung Waste Disposal Area. This research uses a descriptive method with an observational approach while the analysis of lead was conducted by using atomic absorption spectrophotometry (AAS). The results showed that the well water samples contain lead with various concentrations between 0.0060-0.1023 mg/L. Based on the results, it is proved that there is a sample that contains the lead concentration more than the maximum allowable of a lead according to the Minister of Health of Indonesia No. 416/MENKES/PER/IX/1990. The excess of lead concentration in the water samples may be influenced by the distance of the dug wells from the waste disposal area which does not meet the requirements, so the pollution occurs easily. The others parameter which is analyzed in this report is turbidity, color, and temperature of the well water samples.
\end{abstract}

Keywords: Final Waste Disposal Area, Lead Determination, Atomic Absorption Spectrophotometry (AAS) 


\section{PENDAHULUAN}

Sumur merupakan sumber air utama yang masih banyak dimanfaatkan oleh sebagian besar masyarakat Indonesia. Jenis sumber air bersih ini dapat dengan mudah ditemukan di berbagai wilayah di Indonesia. Sumur gali merupakan salah satu sumber air tanah yang berasal dari lapisan tanah yang relatif dekat dengan permukaan tanah. Oleh karena itu, sumur gali merupakan salah satu sumber air yang relatif mudah mengalami pencemaran terutama melalui proses rembesan, terutama jika berada di daerah yang berdekatan dengan sumber bahan pencemar, seperti wilayah Tempat Pembuangan Akhir (TPA) Sampah (Tumanggor, Dharma dan Marsaulina, 2012).

Secara umum terdapat dua sistem pengelolaan sampah di Indonesia, yaitu sanitary landfill dan open dumping. Berdasarkan Undang-Undang No 18 Tahun 2008, TPA Sampah di kota besar dan metropolitan harus direncanakan sesuai metode lahan urug saniter atu sanitary landfill (Astono, Purwaningrum dan Wahyudyanti 2015). Akan tetapi, masih terdapat TPA yang menggunakan sistem open dumping dalam proses pengelolaan sampah, salah satunya yaitu TPA Suwung.

Open dumping adalah sistem pembuangan sampah dengan cara dibuang atau diletakkan begitu saja di tanah lapangan, jurang, atau tempat sampah sehingga dinilai dapat menimbulkan dampak negatif yang lebih luas. Proses penimbunan sampah di TPA dengan sistem open dumping pada umumnya menghasilkan pencemar berupa air lindi (Sumantri, 2013).

Diketahui bahwa sampah yang dikelola di TPA Suwung tidak melalui proses pemilahan, sehingga berbagai jenis sampah yang berpotensi dapat menyebabkan pencemaran logam seperti pigmen plastik, ban bekas, aki bekas, cat bekas, baterai listrik dan pipa ditemukan bersamaan dengan jenis sampah yang lain. Fraksi anorganik di dalam sampah yang mengandung berbagai mineral hingga logam berat tersebut dapat terdekomposisi dan larut bersama terbentuknya air lindi. Logam berat yang sering ditemukan anatara lain adalah arsen, besi, kadmium, kromium, merkuri, nikel seng, tembaga hingga timbal (Fatmawinir, Suyani, dan Alif, 2015).

Beberapa penelitian terdahulu menyebutkan bahwa kandungan logam berat pada air di kawasan TPA memiliki kandungan logam berat $\mathrm{Pb}$ yang melebihi ambang batas yang diperbolehkan. Penelitian yang dilakukan pada sampel air sumur gali di sekitar wilayah TPA Desa Sei Rotan Kecamatan Sei Tuan Kabupaten Deli Serdang menunjukkan kadar timbal yang melebihi ambang batas dengan rentang kadar $0,1-0,13 \mathrm{mg} / \mathrm{L}$ (Tumanggor, Dharma dan Marsaulina, 2012). Hasil serupa juga dilaporkan oleh Nasution dan Silaban (2017) yang menunjukkan bahwa sampel air sumur di sekitar lokasi TPA Muara Fajar mengandung timbal melebihi ambang batas yaitu berada pada rentang 0,25 $0,34 \mathrm{mg} / \mathrm{L}$.

Di sekitar area TPA Suwung, terdapat pemukiman warga yang menggunakan sarana air tanah dangkal sebagai sumur gali. Menurut Kusnoputranto (1997), penyebaran bahan kimia pada air tanah dapat terjadi hingga jarak 25 meter dari sumber pencemar. Area kontaminasi dapat melebar sampai $\pm 9 \mathrm{~m}$ kemudian menyempit hingga jarak $\pm 95 \mathrm{~m}$. Dengan demikian, idealnya sumber air yang digunakan oleh masyarakat sebaiknya memiliki jarak lebih dari $95 \mathrm{~m}$ dari sumber bahan pencemar. Berdasarkan analisis situasi yang telah dilakukan, diketahui bahwa sumur gali yang dimanfaatkan oleh warga sekitar TPA Suwung memiliki jarak kurang dari $95 \mathrm{~m}$, sehingga memungkinkan terjadinya pencemaran air sumur yang berada di kawasan TPA.

Berdasarkan data hasil survey yang telah dilakukan, diketahui bahwa sebagian besar warga yang tinggal di area TPA Suwung masih menggunakan air sumur gali sebagai sumber air utama karena tidak adanya akses air bersih lain yang tersedia. Masyarakat sekitar TPA Suwung menggunakan air sumur gali tersebut untuk kegiatan sehari-hari mulai dari MCK, minuman ternak, bahkan ada beberapa warga yang menggunakannnya 
untuk kegiatan memasak. Minimnya pengetahuan warga tentang pentingnya sumber air bersih yang berkualitas, menyebabkan warga terbiasa menggunakan sumber air yang paling mudah diperoleh tanpa menyadari dampak negatif yang mungkin timbul apabila air yang dikonsumsi tercemar oleh bahan-bahan kimia berbahaya. Hal ini menyebabkan perlunya dilakukan analisis laboratorium untuk mengetahui kandungan polutan yang mungkin terkandung di dalam sumber air tersebut.

Salah satu parameter yang sangat penting untuk mengetahui kualitas air bersih adalah kandungan logam berat terlarut, diantaranya adalah timbal $(\mathrm{Pb})$. Berdasarkan Permenkes RI No. 416/MENKES/PER /IX/1990, kadar maksimum timbal (Pb) yang diperbolehkan dalam air bersih adalah sebesar 0,05 ppm. Timbal diketahui dapat menyebabkan keracunan kronis sehingga menyebabkan kerusakan pada pembentukan sel darah merah hingga gangguan pada sistem reproduksi (Indirawati, 2017; (Sudarmaji, Mukono dan Corie, 2006). Parameter lain yang digunakan untuk mengukur kualitas air menurut Peraturan Menteri Kesehatan RI Nomor 416 Tahun 1990 adalah parameter fisika yang meliputi bau, kekeruhan, rasa suhu serta warna. Pada penelitian ini beberapa parameter fisika yang diukur antara lain adalah kekeruhan, warna, dan suhu.

Analisis kadar timbal dalam penelitian ini dilakukan dengan metode spektrofotometri serapan atom (SSA). Metode ini dilaporkan memiliki sensitivitas dan akurasi yang cukup baik sehingga sesuai digunakan untuk analisis rutin logam terlarut di dalam sampel air. Jika dibandingkan dengan metode spektro fotometer yang lain, SSA memiliki keunggulan karena proses analisisnya dapat dilakukan dengan lebih cepat, selektif dan preparasi sampelnya relatif mudah dilakukan (Sumantri, 2013).

\section{METODE}

Penelitian ini merupakan penelitian deskriptif dengan menggunakan pendekatan observasional. Penelitian ini dilakukan di wilayah TPA Suwung yaitu
Banjar Suwung Batan Kendal, Kelurahan Sesetan, Kecamatan Denpasar Selatan. Sedangkan proses pemeriksaan sampel dilakukan di UPTD Balai Laboratorium Kesehatan Provinsi Bali. Penelitian ini dilakukan dari bulan Februari - April 2019. Populasi dalam penelitian ini adalah sumur gali yang terdapat di wilayah TPA Suwung yaitu Banjar Suwung Batan Kendal, Kelurahan Sesetan, Denpasar Selatan yang berjumlah 11 sumur gali.

Teknik sampling yang digunakan adalah non probability sampling dengan sampling jenuh sehingga seluruh anggota populasi diambil sebagai sampel penelitian (Sugiyono, 2014). Cara pengumpulan data yang digunakan dalam penelitian ini adalah observasi untuk mengetahui jarak antara sumber cemaran dengan sumur gali dan wawancara untuk mengetahui pemanfaatan air sumur gali bagi warga di wilayah TPA Suwung Bajar Suwung Batan Kendal, Denpasar Selatan. Selain itu terdapat beberapa parameter fisika yang dianalisis pada penelitian ini antara lain kekeruhan, warna, suhu, dan bau serta para,meter kimia berupa kandungan timbal dalam air sumur di wilayah TPA Suwung Banjar Suwung Batan Kendal, Denpasar Selatan. Pengukuran kekeruhan sampel dilakukan dengan metode turbidimetri dengan alat Nefelometer Hach Turbidimetri 2100Q, warna sampel diukur secara spektrofotometri dengan alat Spektrofotometer UV-Vis 1610, suhu sampel air diukur dengan termometer air raksa $100^{\circ} \mathrm{C}$, suhu udara diukur dengan alat Termo Hygrometer Hanna HI 9565, bau sampel air diukur secara organoleptik sedangkan kandungan timbal dalam asmpel diukur secara spektrometri dengan menggunakan spektrofotometri serapan atom Hitachi Z-2300. Data yang diperoleh diolah dalam bentuk tabel, grafik dan narasi. 
HASIL DAN PEMBAHASAN

\section{Pengukuran parameter fisika sampel}

\section{a. Kekeruhan sampel}

Kekeruhan merupakan salah satu parameter fisika yang penting untuk menilai kualitas badan air. Kekeruhan menggambarkan sifat optik air yang ditentukan berdasarkan banyaknya cahaya yang diserap dan dipancarkan oleh bahan-bahan yang terdapat di dalam air (Effendi, 2003). Kekeruhan air dapat disebabkan oleh padatan tersuspensi, baik organik yang berasal dari proses pelapukan hewan atau tanaman atau anorganik yang berasal dari pelapukan batuan dan logam. Beberapa limbah buangan juga dapat menjadi penyebab terjadinya kekeruhan pada air. Tingginya kekeruhan air menunjukkan banyaknya partikel-partikel tersuspensi yang terdapat dalam air yang dimungkinkan terjadi karena kontaminasi logam-logam seperti besi, mangan, timbal dan sebagainya (Soemirat, 2009).
Pada penelitian ini, kekeruhan sampel diukur dengan alat turbidimeter yang didasarkan pada prinsip hamburan cahaya oleh sampel. Semakin banyak partikel yang terdapat dalam sampel, maka intensitas cahaya yang dihamburkan semakin banyak sehingga kekeruhan sampel semakin tinggi. Berdasarkan hasil pengukuran kekeruhan sampel dengan alat Nefelometer Hach Turbidimetri 2100Q diketahui bahwa kekeruhan sampel berada pada rentang 0,47 - 2,81 NTU sebagaimana tersaji pada Gambar 1.

Berdasarkan hasil pengukuran tersebut diketahui bahwa seluruh sampel air memiliki kekeruhan pada rentang nilai normal dan tidak melebihi ambang batas yang dipersyaratkan yaitu 25 NTU. Hal ini menunjukkan bahwa sampel air mengandung partikel tersuspensi yang tidak melebihi standar yang dipersyaratkan oleh Permenkes RI No. 416/MENKES/PER/ /IX/1990.

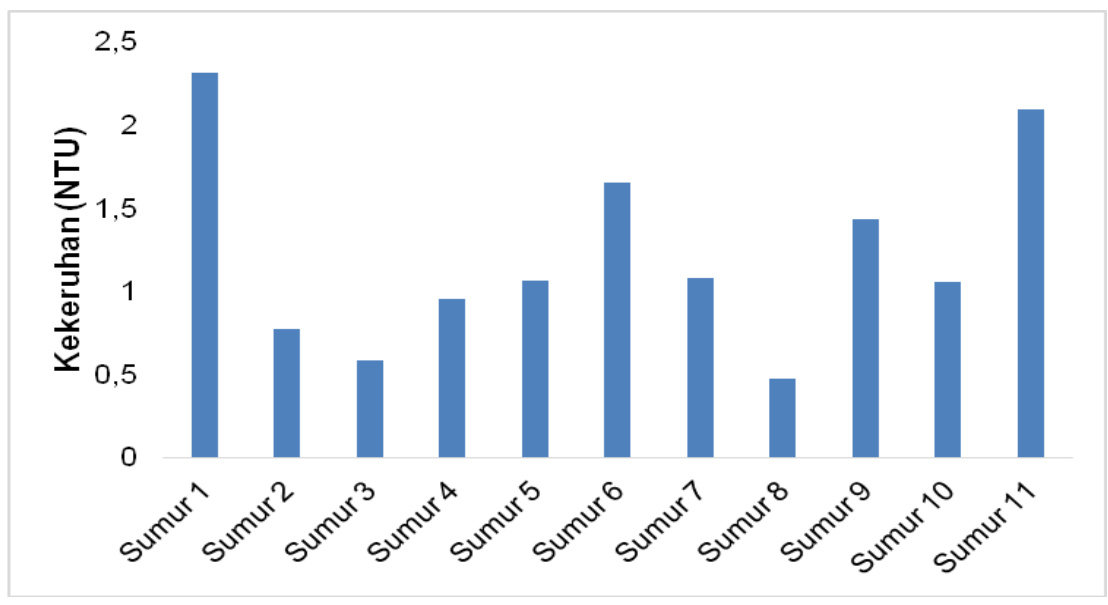

Gambar 1. Hasil Pengukuran Kekeruhan Sampel

\section{b. Warna sampel}

Parameter fisika lain yang digunakan untuk menilai kualitas air adalah warna. Warna yang terlihat pada air dapat disebabkan oleh berbagai faktor antara lain kandungan bahan organik dan anorganik dalam air. Air yang berkualitas seharusnya memiliki warna alami air yang berasal dari kandungan logam terlarut, humus, plankton, atau tumbuhan air lain. Intensitas warna sampel dapat diukur secara spektro fotrometri pada rentang panjang gelombang 450-465 $\mathrm{nm}$ dengan standar Pt-Co (BSN, 2011).

Pada penelitian ini, warna sampel diukur dengan alat Spektrofotometer UV-Visibel 1610. Hasil pengukuran yang telah dilakukan menunjukkan bahwa intensitas warna sampel berada pada rentang 1,527 - 17,369 TCU (True color unit) seperti tersaji pada Gambar 2. 
Berdasarkan hasil pengukuran tersebut, diketahui bahwa semua sampel memiliki warna alami air yang tidak melebihi ambang batas yang dipersayaratkan oleh Permenkes RI No. 416/MENKES/PER /IX/1990 yaitusebesar $50 \mathrm{TCU}$.

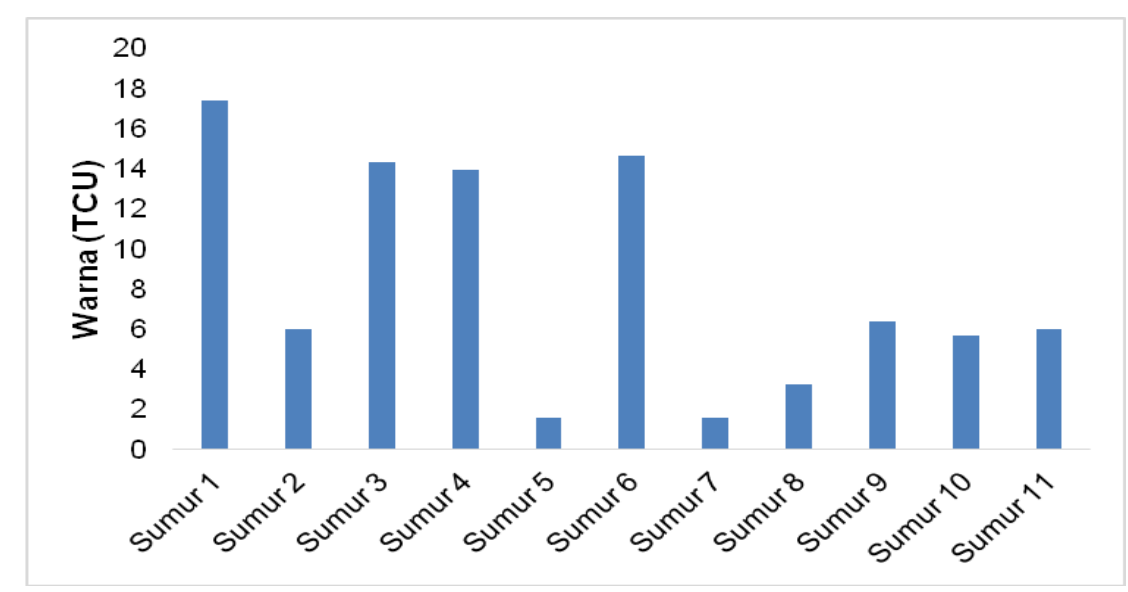

Gambar 2. Hasil Pengukuran Warna Sampel

c. Suhu sampel

Suhu merupakan parameter penting dalam badan air dan berperan penting dalam menentukan kecepatan reaksi penguraian bahan organik maupun anorganik yang terlarut, mempengaruhi tingkat kelarutan garam-garam dan gasgas dalam air terutama $\mathrm{O}_{2}$ yang berperan dalam proses mikroorganisme dan gas $\mathrm{CO}_{2}$ sebagai salah satu komponen penting dalam proses fotosintesis yang menentukan produktivitas lingkungan perairan dan suplai oksigen terlarut. Nilai suhu juga mempengaruhi toksisitas logam berat seperti besi, mangan, kadmium, dan timbale serta reaksi kimia perairan dan juga kelarutan dari berbagai zat di dalam air (Effendi, 2003).

Pada penelitian ini, suhu sampel diukur dengan menggunakan alat termometer. Selanjutnya suhu air yang terukur dibandingkan dengan suhu udara di sekitar sumur gali. Pengukuran suhu udara di sekitar sampel dilakukan dengan alat Termo hygrometer Hanna HI 9565. Data hasil pengukuran menunjukkan bahwa suhu air yang terukur adalah 30 ${ }^{\circ} \mathrm{C}$ dengan rata-rata suhu udara sebesar $33^{\circ} \mathrm{C}$ sebagaimana tersaji pada Gambar 3. Hal ini menunjukkan bahwa semua sampel air memiliki suhu air sesuai standar yang dipersyaratkan.



Gambar 3. Hasil Pengukuran Suhu Sampel 


\section{Analisis kadar timbal (Pb) dalam sampel}

Timbal merupakan salah satu jenis logam berat yang memiliki toksisitas tertinggi. Logam berat ini dilaporkan memiliki efek toksisitas akut dan kronik. Toksisitas akut timbal jarang ditemukan terjadi di masyarakat luas, akan tetapi toksisitas kronik sangat mungkin terjadi tanpa disadari seiring dengan peningkatan sumber paparan timbal di lingkungan. Salah satu sumber paparan timbal dapat terjadi melalui sumber air yang terkontaminasi lindi dari TPA sampah.

Pada penelitian ini, diketahui bahwa sampel air yang dianalisis merupakan sumber air bersih utama yang berada di kawasan TPA yang sangat mungkin terkontaminasi lindi terutama melalui rembesan. Oleh karena itu sangat perlu dilakukan analisis untuk mengetahui kandungan kontaminan yang mungkin terdapat dalam sampel air sehingga dapat meminimalisisr dampak negatif kesehatan yang mungkin timbul.

Analisis kadar timbal dalam sampel air dilakukan dengan metode SSA. Metode SSA merupakan salah satu metode standar yang sesuai digunakan untuk analisis rutin unsur-unsur logam. Metode analisis ini didasarkan pada interaksi antara analit dalam sampel pada skala atomik dengan energi yang berasal dari sumber radiasi. Jika dibandingkan dengan metode yang lain, SSA memiliki beberapa kelebihan karena lebih sensitif, selektif serta akurat (Sumantri, 2013).
Pada penelitian ini, analisis kadar timbal dilakukan dengan alat Spektrofotometri Serapan Atom (SSA) Hitachi Z-2300. Analisis kadar timbal dengan metode SSA diawali dengan tahapan destruksi sampel, kemudian pengukuran absorbansi larutan standar dan dilanjutkan dengan pengukuran absorbansi sampel. Destruksi sampel dilakukan dengan metode basah dengan penambahan asam nitrat pekat ke dalam sampel. Penambahan asam nitrat pekat dilakukan dengan tujuan untuk mengoksidasi timbal dalam sampel sehingga lebih mudah dianalisis. selanjutnya dilakukan pengukuran absorbansi larutan standar timbal dengan rentang konsentrasi 0,1 - 2 ppm pada panjang gelombang 283,3 $\mathrm{nm}$. Berdasarkan data hasil pengukuran larutan standar yang tersaji pada Gambar 4, diketahui bahwa terdapat hubungan yang linier antara absorbansi yang terukur dengan konsentrasi larutan standar dengan nilai slope 0,0106, intersep 0,000006 dengan harga koefisien korelasi sebesar 0,9999. Harga koefisien korelasi yang diperoleh pada pengukuran ini telah memenuhi standar menurut SNI 6989.8.2009 dan menunjukkan bahwa pengukuran yang dilakukan telah memenuhi standar untuk pengendalian mutu dan menandakan bahwa hasil pengukuran akurat (Hasan, 2004).

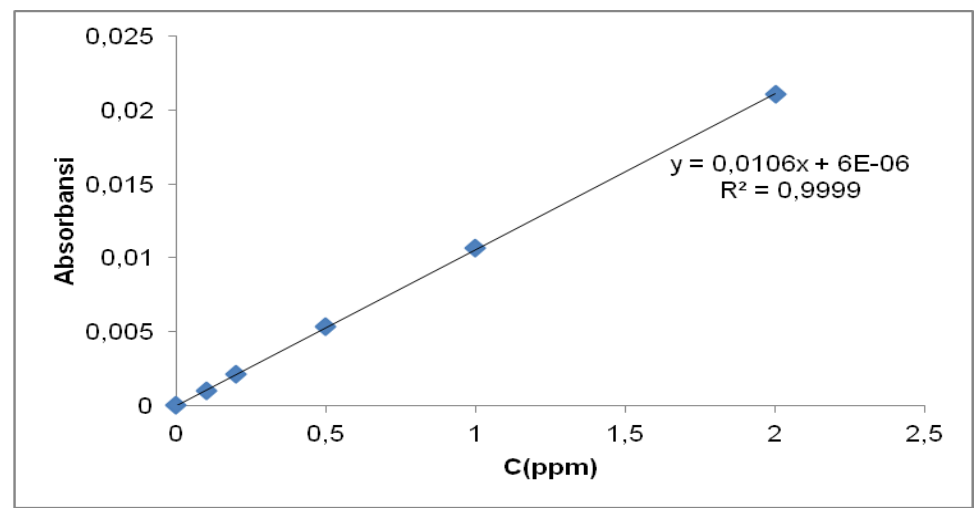

Gambar 4. Kurva Kalibrasi Lautan Standar Timbal 
Berdasarkan hasil pengukuran absorbansi sampel yang telah dilakukan, diketahui bahwa rerata konsentrasi timbal yang terkandung dalam sampel berkisar antara $\quad 0,0060-1,023 \mathrm{ppm}$. Berdasarkan data tersebut diketahui bahwa terdapat 1 sampel yang memiliki kandungan timbal melebihi ambang batas yang diperbolehkan menurut Permenkes RI No. 416/MENKES/PER /IX/1990 yaitu sebesar 0,05 ppm. Tiga sampel yang lain memiliki kandungan timbal dibawah ambang batas, sedangkan tujuh sisanya tidak terdeteksi mengandung timbal, seperti tersaji pada Gambar 5.

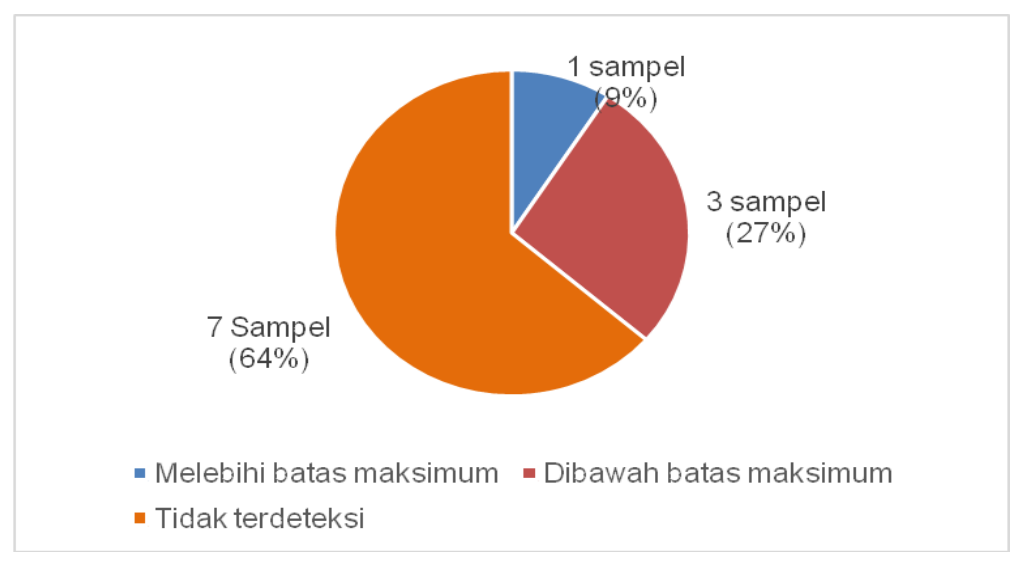

Gambar 5. Hasil Pemeriksaan Kadar Timbal Pada Sampel

Tingginya kadar timbal dalam sampel tersebut dapat disebabkan karena dimungkinkan karena akumulasi hasil dekomposisi sampah organik dan anorganik yang ditimbun di TPA Suwung. Air tanah secara alami mengalir karena adanya perbedaan tekanan dan letak ketinggian lapisan tanah. Air akan mengalir dari tempat yang tinggi ke tempat yang rendah. Letak sumur gali disekitar TPA Suwung berada dibawah tumpukan sampah sehingga mengakibatkan bahan pencemar bersama aliran air tanah dapat dengan mudah mengalir ke bawah hingga mencapai sumur gali.

Berdasarkan hasil wawancara yang telah dilakukan diketahui bahwa penduduk sekitar TPA Suwung telah cukup lama menggunakan air sumur gali sebagai sumber air bersih utama, bahkan ada yang telah mencapai 10 tahun. Sumur yang telah digunakan cukup lama dan volume air yang diambil relatif banyak, menyebabkan aliran air tanah di sekitar sumur semakin mantap dan mendominasi. Selain itu sumber pencemar yang ada di sekitar sumur gali di sekitar TPA Suwung juga semakin banyak sejalan dengan perkembangan aktivitas manusia. Hal ini memberi peluang lebih besar terhadap merembesnya cemaran lindi. Sumur yang digunakan dalam waktu yang relatif lama memiliki kemungkinan tercemar lebih besar karena selain bertambahnya sumber pencemar juga lebih mudahnya sumber pencemar merembes ke dalam sumur mengikuti aliran air tanah yang berbentuk memusat ke arah sumur (Kusnoputranto, 1997).

Limbah padat berupa plastik berwarna hitam, aki bekas dan kaleng cat yang berada di tempat penimbunan kemungkinan menyisakan logam $\mathrm{Pb}$ sehingga dapat mencemari lingkungan dan badan air. Pencemaran ini dapat terjadi oleh adanya proses pengaliran air lindi yang membawa $\mathrm{Pb}$ (Tumanggor, Dharma dan Marsaulina, 2012). Lindi akan mudah terangkut bersama-sama limpasan air hujan dan dapat merembes masuk ke sumur-sumur penduduk yang berada di sekitarnya. Perembesan lindi yang bersifat toksik, mengakibatkan menurunnya kualitas air sumur sesuai dengan peruntukannya (Widyasari, Moelyaningrum, dan Pujiati, 2013). 
Meskipun berdasarkan pengujian diketahui bahwa terdapat sampel yang mengandung timbal dibawah ambang batas dan 7 lainnya tidak terdeteksi, akan tetapi jika sumur tersebut terus menerus digunakan sebagai sumber air bersih utama dalam jangka waktu yang lama maka tidak menutup kemungkinan terjadi peningkatan kadar timbal terlarut sehingga dapat memberikan efek negatif terhadap kesehatan masyarakat.

\section{SIMPULAN}

Berdasarkan hasil pengukuran parameter fisika yang meliputi kekeruhan, warna dan suhu, diketahui bahwa semua sampel memenuhi syarat kualitas air bersih. Sedangkan berdasarkan hasil analisis timbal diketahui bahwa terdapat sampel yang mengandung kadar timbal melebihi ambang batas yang dipersayaratkan oleh Permenkes RI No. 416/ MENKES/PER/IX/1990.

Berdasarkan hasil penelitian tersebut, disarankan kepada pihak terkait seperti dinas kesehatan atau puskesmas setempat untuk dapat memberikan edukasi tentang pentingnya penggunaan air bersih yang berkualitas. Selain itu diperlukan monitoring yang kontinyu terhadap beberapa parameter kualitas air untuk mencegah munculnya dampak negatif kesehatan di masyarakat.

\section{DAFTAR PUSTAKA}

Astono, W., P. Purwaningrum, dan R. Wahyudyanti. 2015. Perencanaan Tempat Pembuangan Akhir Sampah dengan Menggunakan Metode Sanitary Landfill Studi Kasus: Zona 4 TPA Jatiwaringin, Kabupaten Tangerang. 7(1): 7-15.

Badan Standarisasi Nasional. 2011. Air dan Air Limbah-Bagian 80: Cara Uji Warna Secara Spektrofotometri. SNI 6989.80:2011.

Effendi, H. 2003. Telaah Kualitas Air Bagi Pengelolaan Sumber Daya dan Lingkungan. Yogyakarta: Kanisus.

Fatmawinir, H. Suyan, dan A. Alif. 2015. 'Analisis Sebaran Logam Berat Pada Aliran Air Dari Tempat Pembuangan Akhir (TPA) Sampah Air Dingin'. Jurnal Ris. Kim., 8(2):
101-107.

Hasan, I. 2004. Analisis Data Penelitian dengan Statistik. Jakarta: PT Bumi Aksara.

Indirawati, S.M. 2017. Pencemaran Logam Berat $\mathrm{Pb}$ Dan $\mathrm{Cd}$ Dan Keluhan Kesehatan Pada Masyarakat Di Kawasan Pesisir Belawan. 2: 54-60.

Kusnoputranto, H. 1997. Kesehatan Lingkungan. Jakarta: Direktorat Jenderal Pendidikan Tinggi, Departemen Pendidikan dan Kebudayaan.

Nasution, H.I, dan S. Silaban. 2017. 'Analisis Logam Berat Pb Dan Cd Dalam Air Sumur Di Sekitar Lokasi Pembuangan Sampah Akhir'. Jurnal ITEKIMA.1(1). 17-24.

Soemirat, J. 2009. Kesehatan Lingkungan. Yogyakarta: Gajah Mada University Press.

Sudarmaji, J. Mukono, dan Corie. 2006. 'Toksikologi Logam Berat B3 Dan Dampaknya Terhadap Kesehatan'. 1(23). 129-143.

Sugiyono. 2014. Metode Penelitian Kualitatif, Kuantitatif, Dan R\&D. Bandung: Alfabeta.

Sumantri. 2013. Kesehatan Lingkungan. Jakarta: Kencana Prenada Media Group.

Suyono dan Budiman. 2014. IImu Kesehatan Masyarakat Dalam Konteks Kesehatan Lingkungan. Jakarta: Penerbit Buku Kedokteran. ECG.

Tumanggor, W.R.E., S. Dharma, dan I. Marsaulina. 2012. Analisis Kandungan $\mathrm{Pb}$ Pada Air Sumur Gali Masyarakat Di Sekitar Tempat Penimbunan Limbah Padat Industri Timah Dari Daur Ulang Aki Bekas Desa Sei Rotan Kecamatan Sei Tuan Kabupaten Deli Serdang Tahun 2012. 1-7.

Widyasari, N., A. D, Moelyaningrum., dan R. S. Pujiati. 2013. Analisis Potensi Pencemaran Timbal (Pb) Pada Tanah, Air Lindi Dan Air Tanah (Sumur Monitoring) Di TPA Pakusari Kabupaten Jember, Artikel Ilmia Hasil Penelitian Mahasiswa 2013, pp. 1-8. 